ISSN 2519-2523 (print)

Chornomors'ka mynuvshyna. - 2020. - No.15

DOI: $10.18524 / 2519-2523.2020 .15 .218683$

УДК 94 (477)

\title{
PRESENTATIONS OF THE HISTORY OF RIGHT-BANK AND LEFT-BANK UKRAINE IN MODERN REGIONAL AND HISTORICAL TEXTS: POSING THE PROBLEM
}

\author{
Liyudmyla Novikova \\ ORCID: https://orcid.org/0000-0003-4764-7867 \\ $\mathrm{PhD}$ (History), Associate Professor \\ Odessa I. I. Mechnikov National University \\ 2, Dvoryanska Str., Odessa, 65082, Ukraine \\ lyudmilanovikova@hotmail.com
}

Despite the development in modern historical science of such areas as historical local history and historical regional studies, the specifics of the historiographic presentation of Ukrainian regions in the modern period remains insufficiently studied. In this study, an attempt was made to determine the complex structure of historiographic interpretations of Left-Bank and Right-Bank Ukraine in modern times, which coexisted and were manifestations of transformations of social identity, to outline this issue as a separate scientific problem in the field of historical regional studies. It was found that historiographical presentations of the history of Right-bank and Left-Bank Ukraine in the XIX - early XX century had a complicated structure. The history of the Right Bank (or its subregions) was included in the context of "Western-Russian" history, the history of the western part of the Russian Empire, the Polish concept of "oriental kreses", as well as the paradigm of national Ukrainian history. The latter also experienced transformation, in particular, from the history of Kievian land and South-Western Russia, Little Russia to the history of Ukraine itself. In this regard, in the late XIX century, there were works specifically devoted to the history of "RightBank Ukraine".

A similar evolution is experienced by the presentation of the history of the Left-Bank Ukraine (its subregions). At the same time, there was also its own specificity, determined by the fact that it was the territory of the former Left-Bank Hetmanate. As a result, there was such a presentation of the history of the region as the history of the Cossack regiments (as administrative territories).

At the same time, there is a tendency at the edge of the XIX and XX centuries to consider the history of the region as the history of "Left-Bank Ukraine". The question of how the history of LeftBank Ukraine was reflected in the context of the "West-Russian" concept remains open, although its reflection is present in the related regional ("oblast" or "land") one.

Key words: historiographic interpretations of the history of Left-Bank Ukraine in modern times; historiographic interpretations of the history of Right-Bank Ukraine in modern times; "Western-Russia"n historiographic concept; paradigm of national Ukrainian history.

Людмила Новікова

ORCID: https://orcid.org/0000-0003-4764-7867

Кандидат історичних наук, доцент Одеський національний університет імені I.I. Мечникова Вул. Дворянська, 2, Одеса, 65082, Україна lyudmilanovikova@hotmail.com 


\section{ПРЕЗЕНТАЦІЇ ІСТОРІЇ ПРАВОБЕРЕЖНОЇ ТА ЛІВОБЕРЕЖНОЇ УКРАЇНИ В МОДЕРНИХ РЕГІОНАЛЬНО-ІСТОРИЧНИХ ТЕКСТАХ: ДО ПОСТАНОВКИ ПРОБЛЕМИ}

Незважаючи на розвиток у сучасній історичній науці таких напрямків, як історичне краєзнавство та історична регіоналістика, недостатньо вивченим залишається специфіка історіографічної презентації українських регіонів у модерний період. У даному дослідженні здійснена спроба визначити складну структуру історіографічних інтерпретацій історії Лівобережної та Правобережної Украӥни в модерну добу, щзо співіснували й були проявами трансформацій суспільної ідентичності, окреслити це питання як окрему наукову проблему в галузі історичної регіоналістики.

Було встановлено, що історіографічні презентації історії Правобережної та Лівобережної України у ХIX - на початку XX cm. мали складну структуру. Історія Правобережжя (або його субрегіонів) включалася в контекст «західноруської》 історії, історії західної частини Російської імперї, польської концепції «східних кресів», а також до парадигми національної украӥнської історії. Остання теж переживала трансформацію, зокрема, від історії Київської землі та Південно-Західної Русі, Малоросії до власне історії України. У зв'язку з ичим наприкінці XIX cm. з'являються праціi, спеціально присвячені історії «Правобережної України».

Подібну еволючію переживає і презентація історії Лівобережжя (його субрегіонів). Водночас тут була й своя специфіка, визначена тим, щчо це була територія колишньої Лівобережної Гетьманщини, внаслідок чого наявна така презентація історії регіону як історії полків. Водночас спостерігається тендениія до переходу на межі XIX-XX cm. до розгляду історії регіону власне як історї «Лівобережної Украӥни». Відкритим поки що залишається питання те, як історія Лівобережної України відображалася в контексті «західноруського» підходу, хоча вона і висвітлювалася в контексті пов'язаної, на наш погляд, з ичи підходом обласної (земельної) концепції.

Ключові слова: історіографічна інтерпретація історії Лівобережної Украӥни в модерний період; історіографічна інтерпретація історії Правобережної України в модерний період; «західноруська» конщепція; парадигма національної історії Украӥни.

Незважаючи на розвиток у сучасній історичній науці таких напрямків, як історичне краєзнавство та історична регіоналістика, недостатньо вивченим залишається специфіка історіографічної презентації українських регіонів у модерний період. Зокрема, це стосується Правобережної та Лівобережної України. Хоча дослідження історії вивчення Правобережжя та Лівобережжя має помітну історіографію, представлену працями Л. В. Баженова, С. Е. Баженової, О. І. Журби, О. Коваленко та ін. [1-5], однак, на наш погляд, існує потреба більш докладного висвітлення питання щодо співіснування в умовах Російської імперії різних інтерпретацій історії регіону, що мали національний характер.

Мета даного дослідження - обгрунтувати наявність складної структури історіографічних інтерпретацій історій вказаних регіонів в модерну добу, що співіснували й були проявами трансформацій суспільної ідентичності, окреслити це питання як окрему наукову проблему в галузі історичної регіоналістики.

Презентації історії Правобережної України. Однією $з$ форм історіографічної презентації історії Правобережної України в Російській імперії було висвітлення регіональної або відповідної предметної історії у контексті «західноруської» концепції, тобто крізь призму наративу щодо розколу території колишньої Русі, відділення різними країнами «Західної Русі» та згодом іiі «повернення» до складу Російської імперії, яка в офіційній імперській історіографії розглядалася як спадкоємиця Русі. 
Праці, засновані на використанні цієї концепції, відповідали так званому «антидотному» («антиотрутному») напрямку політичної літератури, що існував у Російській імперії з другої половини XVIII ст., 3 метою виправити «неправильні» уявлення щодо імперії, які поширювалися в Європі. Подібний характер мала й «записка» «Взгляд на историю Западной Руси» (СПб., 1848) [6]. Автор висловлював думку, що історики до початку XIX ст. подавали спільну історію Русі тільки до XII ст., як Нестор-літописець, а потім зосереджувалися на історії східної Русі (Московської держави), ігноруючи історію Західної Русі. Це сформувало невірні уявлення щодо «найважливішої частини руської історії, яка залишалася без пояснення» (тут і далі переклад українською автора статті) [6, с. V], тобто уявлення про відношення «Західної Русі» до Польщі. Внаслідок відсутності подібної інформації поширюється співчуття польському рухові в Свропі [6, с. VII]. Особливу увагу автор «записки» приділяє подіям в «Південній частині Західної Русі» в Речі Посполитій, ролі козацтва, яке займало територію, що спершу називалася Україною, а згодом Малою Росією [6, с.17]. Подібна концепція властива монографії М. Кояловича «Чтения по истории Западной России» (1884) [7].

Отже, відповідно цій концепції, історія Правобережжя мала бути вписана в контекст історії Південно-Західної Русі (тобто територіально України). Представляє інтерес те, що адміністративно-територіальна термінологія поширювала поняття «Південно-Західного краю» саме на три губернії переважно Правобережної України, хоча $з$ історіографічної точки зору даного кола авторів, як можна дійти висновку, це мала бути вся Україна за межами «Східної Русі».

У певному зв'язку 3 «західноруськими» працями знаходяться видання, присвячені західній частині Російської імперії, які видавалися МВС з 1858 р. Згодом, у 1887-1890 pр., до 900-річчя хрещення Русі виходить серія під загальною назвою (в інтерпретації її видавця К. Батюшкова) «Памятники русской старины в западных губерниях» Російської імперії. Вона, зокрема, включала нариси, присвячені «Волині» та «Поділлю». Отже, історія Правобережної України розглядалася і в контексті історії західної части Російської імперії. Історія Поділля, наприклад, в очах видавця підтверджувала те, що Поділля, «населене з давніх часів слов'яно-руським племенем, довго знаходилося під чужоземним ігом, не втратило особливостей землі руської», що у XVIII ст. «повернулася до Росії» [8, с. XI-XII]. Поряд 3 конкретним ідеологічним завданням, книги серії включали багатий фактичний матеріал, ілюстрації місцевих памяток, портрети світських та церковних діячів та ін. У виданні з історії Волині його автор, М. І. Петров, поставив мету «...вміщувати тільки такі події з життя Волині, які сприяли чи перешкоджали розвитку руської народності та православ'я» [9, с. 4].

Важливий крок у напрямку до вироблення національної концепції української історії зробив М. О. Максимович, який пропагував концепцію «Київської землі» (України). Певне підтвердження такого ставлення М. О. Максимовича до «Київської землі» знаходимо у його роздумах щодо можливості перетворення альманаха «Киевлянин» в спеціальний журнал, що мав би виходити 6 книгами на рік. Міркуючи про нове видання, М. О. Максимович говорить про можливість назвати його якщо не «Киевлянин», «...то «Украинским зрителем» или «Малороссийскою скрынею»...» (у своєму листі до Й. М. Бодянського, 18 квітня 1857 р.) [10, с. 47].

Коментарі М. О. Максимовича 3 приводу історії Правобережжя нагадують принципові положення «західноруського» підходу. Водночас його концепція «Київської землі» відкриває шлях до розуміння регіональної історії в українському контексті. Зокрема, у своєму листі до Д. Г. Бібікова у 1884 р. $з$ приводу актів 
Луцького братства він відзначав: «Акти ці істинно дорогоцінні, бо представляють собою нове свідчення про те, з яким старанням і якими засобами Волинська Русь оберігала у минулі часи православну віру, яка складає основну й головну стихію народності нашої, для якої ціла Русь стільки віків жила та діяла» [10, с. 21].

3 іншого боку, формується напрямок так званої обласної (земельної) історії, представники якого зосереджуються на самобутньому періоді історії окремих земель Русі до XIV ст., коли вони включаються до складу Польщі, Литви та ін. Останній напрямок часто пов'язується з В. Б. Антоновичем та представниками його київської історичної школи. Водночас не слід виключати вплив на формування обласного чи земельного напрямку «західноруської» концепції, яка проводила чітку лінію між історією Русі до та після входження ії̈ земель до Литви та Польщі у XIV ст. Одним 3 прикладів є праця П. А. Іванова «Судьбы Волынской земли с древнейших времен до конца XIV века» (1895) [11].

Історія Правобережної України в польській історіографії часто розглядалася як історія «східних кресів» (окраїн) Речі Посполитої. Це було властиво для істориків краківської історичної школи та пов'язаної з нею «української історичної школи» в польській історіографії [2, с. 10-11], представником якої був Ю. А. Роллє (Кам'янецьПодільський). Він 31876 р. до 1893 р. опублікував дев'ять серій «Історичних оповідей», що стосувалися історії Правобережної України, а також інші збірки. Серед останніх ілюстративною є збірка під назвою «Наречені кресів, історичні оповіді» (1883) [3]. Ми згадуємо праці Ю. А. Роллє з огляду на те, що вони мали високу історичну вартість завдяки унікальному джерельному матеріалу, використаному для їх написання, а його внесок у висвітлення історії регіону був визнаний з боку істориків-сучасників.

Історія регіону як власне історія Правобережної України розглядається як специфічний предмет вже в умовах розвитку української етнічної історіографії, як окремого історіографічного напрямку. Прикладом є робота О. Я. Єфименко «Очерки истории Правобережной Украины» (К., 1895) [13], написана на основі праць Ю. А. Роллє, присвячених історії регіону. Водночас слід відзначити, що термін «правобережна Україна» зустрічається і у більш ранніх працях, зокрема, в роботі М. О. Домонтовича, коли він звертається до опису одного 3 повстань першої половини XVII ст. [12, с. XII].

Визнаючи великий внесок Ю. А. Роллє у вивчення історії Правобережної України, О. Я. Єфименко практично визначає концептуальне значення його праць, хоча пізніше, дещо суперечливо зі спробою окреслити роботи Ю. А. Роллє як частину предметної української історіографії, у самої О. Я. Єфименко виходить збірка досліджень з історії України під назвою «Южная Русь» (як Україна) [14].

Авторка «Очерков» відтворює оригінальну картину загальної історії Правобережної України, починаючи з історії субрегіонів, що іiі складали: Волині, Побужжя, Київське Полісся, Подністров'я. О. Я. Єфименко звертає увагу на демографічні процеси в регіоні, виділяючи області «початкового старо-руського заселення» та нового. Вона стежить за суспільними відмінностями в історії субрегіонів, що залежали від дії різних чинників, формували різні суспільні типи [14, c. 3-4]. Зокрема, дослідниця відзначає, що на Волині та Київському Поліссі «руський елемент розвивався повністю самостійно, без впливу якихось однобічних впливів», а у Подністров'ї відчувався сильний польський вплив [14, с. 5, 8], Представляє інтерес певна антипольська спрямованість тексту О. Я. Єфименко, що, однак, була пов'язана зі співчуттям до становища українців, а не була визначена спробою пояснити 
входження Правобережжя до Російської імперії [14, с. 151]. Певна увага в «Очерках» приділяється історичній психології на Правобережжі [14, с.163], що детерміновано, очевидно, тим матеріалом, 3 яким, як 3 джерелом, працювала О. Я. Єфименко роботи Ю. А. Роллє були роботами не тільки краєзнавця, але й лікаря-психіатра.

Окремою формою презентації історії Правобережної України були церковноісторичні дослідження, історико-статистичні описи єпархій, в яких предметна структура охоплює як світську, так і церковну історію, з домінуванням останньої. Як приклад, слід згадати про розвідку М. І. Теодоровича «Историко-статистическое описание церквей и приходов Волынской епархии» (у 5 тт., Почаєв, 1888-1903). Автор зазначив, що присвячує свою працю поборникам «Православ'я та руської народності на Волині». Волинь він розглядає в межах єпархії, а також як одну 3 західноруських областей. У першому томі М. І. Теодорович викладає «Короткий нарис історії Волині». Звертаючись до середньовіччя, автор вказує на те, що у східній частині Волині проживали древляни, в західній та Галичині - волиняни/бужани, простежує підкорення Волині та Галичини князям Русі, історію «знаменитого Галицько-Волинського князівства або королівства Даниїла» [15, с.10]ю Останнє він розглядає як «давню власність Росії, набуту зброєю Олега та святого Володимира» що була розділена «між чужоземцями», втративши після приєднання галицьких князів до Польщі свою незалежність назавжди. Звертаючись до питання поширення на Волині християнства, автор вказує на те, що вона була однією з перших руських земель, де поширилось християнство. Згадуючи про гіпотезу щодо ролі в цьому моравського просвітника Мефодія, Теодорович певним доказом цього ввапжає те, що занепад Моравської держави супроводжувався еміграцією християн [15, с. 14-15]. Автор наводить переліки та біографічні дані православних єпископів в єпископських центрах Володимирі, Луцьку, а також - у примітках - переліки місцевих уніатських єпископів. Значну увагу автор приділяє церковно-релігійній історії, вказуючи на те, що «Литва не притісняла, а засвоювала руську народність» [15, с. 22], а поляки, фанатично переслідуючи руську мову і взагалі руську народність, «робили руську людину поляком» [15, с. 24]. Тому автор високо оцінює 1793 р., як «кінець святкуванню ворогів православ'я» [15, с. 24], трактуючи приєднання Волині та Правобережжя як «повернення» давньої власності, вказує на масове навернення до православ'я наприкінці XVIII ст. [15, с. 24-25]. Таким чином, погляди М. I. Теодоровича співвідносяться 3 поглядами прибічників «західноруської» історіографічної концепції.

Окремо слід відзначити, що представники різних історіографічних напрямків, згаданих вище, часто формували уявлення щодо історії Правобережної України як історії історично православного регіону.

Особливості презентації історії Лівобережної України. Іспорія Лівобережної України активно висвітлювалася представниками обласного (у розумінні земельного) історіографічного напрямку. У поле зору дослідників при цьому потрапляли окремі субрегіони, такі, як історична «Сіверська земля». Зокрема, слід згадати дослідження Д. І. Багалія «История Северской земли до половины XIV ст.» (1882) [16]. Тим самим історія Лівобережної України (або іï субрегіони) поставали як складові середньовічної Русі.

Окремо слід згадати про представлення історії Лівобережної України у вигляді історії іiі субрегіонів, визначених в межах адміністративно-територіального поділу, зокрема, губерній. (Чернігівської, Полтавської, зокрема), Прикладом є офіційні дослідження, здійснені офіцерами генерального штабу, зокрема, М. О. Домонтовича [12]. 
М. О. Домонтович починає історію губернії задовго до їі офіційного створення і доводить ії до 1808 р.. коли після створення у 1802 р. Чернігівської губернії було завершено створення іiі повітів. 3 цього часу, відзначає автор, «історія іiі (Чернігівської губернії) стає нероздільною з історією Російської [у автора - Русской] імперії» [12, c. XXI]. Практично історія губернії є історія населеної місцевості, яка входить у межі губернії. Автор починає з часів заселення території слов'янами, згадуючи версію Нестора-літописця щодо переселення їх з Дунаю. Далі він виходить за межі губернії, звертаючись до долі історичних Сіверської землі, Чернігівського уділа. Так, згадуючи про підпорядкування Сіверської землі Києву, він відзначає, що далі був період 160річної спільної історії, а самостійне життя уділу почалося зі Святослава Ярославича. При цьому автор вказує на розміри Чернігівського уділу, які виходили далеко за межі Чернігівської губернії, включаючи частини білоруських та російських губерній, сучасних автору $[12$, с. II, IV]. М. О. Домонтович висвітлює історію громадянськості (суспільства), визначає значення кожного наступного періоду, включно 3 періодом Гетьманщини. Автор вказує на позитивне значення для регіону перебування його під владою Литви - були відсутні перепони для розвитку місцевої громадянськості тощо [12, с. VIII], намагається пояснити значення для регіону періоду перебування в Московському царстві, негативно оцінює політику Польщі, направлену на знищення «південно-руської громадянськості» [12, с. ХІІ]. Особливістю роботи є те, що іноді брак конкретного регіонального матеріалу М. О. Домонтович заповнює загальною історичною концепцією.

Історія Чернігівщини часто розглядається в сукупності з історією Чернігова, виступаючи своєрідним історичним тлом для історії міста. Тут ми зустрічаємося, очевидно, 3 існуванням своєрідного «протографу» такого підходу, коли існував початковий подібний текст, а далі вже дослідники «успадковували» вже існуючий підхід. 3 цим ми зустрічаємося у вже згаданій праці М. О Домонтовича, а також пізніше, вже на початку XX ст., у ювілейній роботі, присвяченій тисячолітній історії м. Чернігова [17].

Окремим видом презентації місцевої історії $є$ історія єпархії, зокрема, в праці архієпископа Філарета Гумілевського «Описание Черниговской епархии» (Чернігів, 1873 р., у 5 книгах).

Особливим напрямком висвітлення історії Лівобережної України було зображення iї як історії Гетьманщини. У зв'язку з цим слід згадати працю О. М. Лазаревського «Описание старой Малороссии», який пропонує бачення історії Лівобережжя як історії українських адміністративно-територіальних одиниць - полків [18]. О. М. Лазаревський називає територію колишньої Гетьманщини Малоросією, тобто вживає цей термін у даному випадку у вузькому значенні, а не як синонім України. У передмові до свого кількатомного видання О. М. Лазаревський відзначав, що у його праці дається опис «Малоросії лівого берега Дніпра», що тепер складає Чернігівську та Полтавську губернії. Зустрічається у історика й термін «Лівобережна Україна» [19, с. 1-5].

Своїм завданням дослідник ставив опис всіх 10 полків Лівобережної Гетьманщини, «вважаючи, що наша книга дасть певні матеріали для вивчення народного життя, яке у написаних дотепер історіях Малоросії так сильно заслонена переказом подій зовнішньої історії» [18, с. III]. Хронологічні межі своєї праці О. М. Лазаревський визначав від «...приєднання Малоросії до руської держави у 1654 р. до введення в ній загальноросійських [у автора - «общерусских»] форм громадянського управління у 1782 р...». Дослідник встиг видати, крім першого, томи, 
присвячені історії Ніжинського (1893), Прилуцького полків (1902). Опис кожного полку О. М. Лазаревський починав «історичним нарисом місцевості, на якій розташований полк» $[19$, с. 1$]$.

На питаннях внутрішньої, соціальної історії Гетьманщини зосереджував увагу учень Д. І. Багалія В. О. Барвінський у своїй розвідці, вміщеній у «Записках НТШ» українському загальнонаціональному у свій час науковому виданні - під назвою «До історії закріпощення селян в Лівобічній Україні» [20, с. 154-157, Miscellanea]. Під останньою автор має на увазі Гетьманщину. Автор звертається до історії суспільного життя на Україні, вказує на закономірність появи явища кріпацтва, властивого різним країнам (вплив марксизму?). В. О. Барвінський простежує еволюцію інтересів, появу конфлікту між «поспольством» та державцями (вже на кінець XVII ст.), вважає кріпосне право результатом внутрішнього розвитку Гетьманщини [20, с. 155].

Інша стаття В. О. Барвінського у «Записках НТШ» присвячена також питанням внутрішньої історії «Лівобережної України», «Лівобережжя». Автор публікує документи 3 Румянцевського опису, присвячені «...малодослідженій соціяльно-економічній історії лівобережної України» [21, с. 25], а саме питанням землеволодіння, скуповуванню козацької землі, яке В. Барвінський характеризує як невпинне суспільне явище в регіоні, незважаючи на діючий заборонний указ 1739 р., кредитній активності представників козацтва тощо [21, с. 26-28].

Отже, історіографічні презентації історії Правобережної та Лівобережної України у XIX - на початку XX ст. мали складну структуру. Історія Правобережжя (або його субрегіонів) включалася в контекст «західноруської» історії, історії західної частини Російської імперії, польської концепції «східних кресів», а також до парадигми національної української історії. Остання теж переживала трансформацію, зокрема, від історії Київської землі та Південно-Західної Русі, Малоросії до власне історії України. У зв'язку з цим наприкінці XIX ст. 3'являються праці, спеціально присвячені історії «Правобережної України». Подібну еволюцію переживає i презентація історії Лівобережжя (його субрегіонів). Водночас тут була й своя специфіка, визначена тим, що це була територія колишньої Лівобережної Гетьманщини, внаслідок чого наявна така презентація історії регіону як історії козацьких полків. Водночас спостерігається тенденція до переходу на межі XIXXX ст. до розгляду історії регіону власне як історії «Лівобережної України». Відкритим залишається питання те, як історія Лівобережної України відображалася в контексті «західноруського» підходу, хоча вона й висвітлювалась в контексті пов'язаної, на наш погляд, з цим підходом обласної (земельної) концепції .

\section{Джерела та література:}

1.Баженов Л. В. Історичне краєзнавство Правобережної України XIX - на. початку XX ст. Становлення. Історіографія. Біобібілографія./ Л. В. Баженов. - Хмельницький, 1995. - 255 с.

2. Баженов Л. В. Регіональна історія України в дослідженнях краківської історичної школи (60-ті pр. XIX ст. - початок XX ст.) / Л. В. Баженов // Вісник Кам'янець-Подільського національного університету ім. І. Огієнка. Історичні науки. - 2016. - Вип. 9. - С. 8-16.

3. Баженова С. С. Юзеф Антоній Роллє: життя, діяльність, творчість. 2-е видання. / С. Є. Баженова. - Кам'янець-Подільський, 2002. - 180 с.

4. Журба О. І. Київська археографічна комісія, 1843-192: нарис історії і діяльності./ О. І. Журба. - Київ: Наук. думка, 1993. - 184 с.

5. Коваленко О. Головні етапи розвитку історичного краєзнавства на Чернігово-Сіверщині /

О. Коваленко // Краєзнавство. - 2000. - № 1. - С. 39-45.

6. Взгляд на историю Западной Руси. - СПб., 1848. - VIII - 65 с. 
7. Коялович М. И. Чтения по истории Западной России. / М. И. Коялович. - СПб.: Тип. А. С. Суворина, 1884. - XIII, [3]. - 349 с.

8. Петров Н. И. Подолия. Историческое описание / Н. И. Петров. - СПб., 1891. - 401 с.

9. Петров Н. И. Волынь. Исторические судьбы Юго-Западного края. / Н. И. Петров. - СПб., 1888. - 438 c.

10. Максимович М. Листи / М. Максимович. - Київ: Либідь, 2004. - 312 с.

11. Иванов П. А. Судьбы Волынской земли с древнейших времен до конца XIV века / П. А. Иванов. - Одесса, 1895. - 328 с.

12. Домонтович М. Материалы для географии и статистики России, собранные офицерами Генерального штаба. Черниговская губерния / М.Домонтович. - СПб.: Тип. Ф. Персона, 1865. $796 \mathrm{c}$.

13. Ефименко А. Я. Очерки истории правобережной Украины. / А. Я. Ефименко. - Киев: Тип. Г. Т. Корчак-Новицкого, 1895. - 2, 174 с.

14. Ефименко А. Я. Южная Русь: очерки, исследования, заметки: в 2 т. / А. Я. Ефименко. СПб.: Книгопечатня Шмидта, 1905. - Т. 1. - 439 с.

15. Теодорович Н. И. Историко-статистическое описание церквей и приходов Волынской епархии. / Н. И. Теодорович - Почаев, 1888. - Т. 1. - 432, IV с.

16. Багалей Д. История Северской земли до половины XIV ст. Историческая монография. / Д. Багалей. - Киев, В университетской типографии (И.И.Завадского), 1882. - I, 310, [2], II с.

17. Очерк истории города Чернигова, 907-1907: юбил. изд. Чернигов. Гор. Управы. Чернигов: Тип. Губ. Земства, 1908. - 71 с.

18. Лазаревський А. М. Описание старой Малороссии. Т. 1.: Полк Стародубский. / А. М. Лазаревський. - К., 1888. - XVI, 470, XXX с.

19. Лазаревский А. М. Описание старой Малороссии. Т. 2.: Полк Нежинский. / А. М. Лазаревський. - К., 1893. - IV, 521, XXV с.

20. Барвінський В. До історії закріпощення селян в Лівобічній Україні / В. Барвінський // Записки НТШ. - 1908. - Т. 81. - Кн. 1.- С. 154-155. Miscellanea.

21. Барвінський В. Матеріали до історії суспільному та економічного побуту Лівобережної України в XVIII ст. / В. Барвінський // Записки НТШ. - 1909. - Т. 90. - Кн. 4.- С. 25-32.

\section{References:}

1. Bazhenov, L. V., 1995. Istorychne kraieznavstvo Pravoberezhnoi Ukrainy XIX-na pochatku XX st. Stanovlennia. Istoriografiia. Bibliografiia [Historical local history of the Right-Bank Ukraine in the XIX - at early XX century. Formation. Historiography. Biobibilography]. Khmel'nytsky. [in Ukrainian].

2. Bazhenov, L. V., 2016. Regionalna istoriia Ukrainy v doslidjenniakh krakivs'koi istorychnoi shkoly (60-ti rr. XIX st. - pochatok XX st.) [Regional history of Ukraine in the research of Krakow Historical School (60's of the XIX c. - early XX c.)]. Visnyk Kam'yanets'-Podil's'kogo natsionalnogo universitetu im. I. Ogienka. Istorychni nauky, 9, pp. 8-16. [in Ukrainian].

3. Bazhenova, S. Ye., 2002. Yuzef Antonii Rollie: zhyttia, diial'nist', tvorchist' [Josef Anthony Rolle: life, activities, creativity] 2nd. Kam'yanets'-Podil's'kyi. [in Ukrainian].

4. Zhurba, O. I., 1993. Kyivs'ka arkheografichna komissiia, 1843-1921: narys istorii i diial'nosti [Kyiv Archeographical Commission, 1843-1921: essay of history and activity]. Kyiv: Naukova dumka. [in Ukrainian].

5. Kovalenko, O., 2000. Golovni etapy rozvytku istorychnogo kraieznavstva na ChernigovoSiverschyni [The main stages of development of historical local history in Chernihiv-Siverschyna]. Kraieznavstvo, 1., pp. 39-45. [in Ukrainian].

6. Vzgliad na istoriiu Zapadnoi Rusi [A look at the history of Western Russia], 1848. SPb. [in Russian].

7. Koialovich, M. I., 1848. Chtieniia po istorii Zapadnoi Rossii [Readings on the history of Western Russia]. SPB.: Tip. A. S. Suvorina. [in Russian]. 
8. Petrov, N. I., 1891. Podoliia. Istoricheskoie opisaniie [Podolia. Historical description]. SPb. [in Russian].

9. Petrov, N. I., 1888. Volyn'. Istoricheskiie sud'by Yugo-Zapadnogo kraia [Volyn. Historic fates of the South-West region]. SPB. [in Russian].

10. Maksymovych, M., 2004. Lysty [Letters]. Kyiv: Lybid'. [in Ukrainian].

11. Ivanov, P. A., 1895. Sud'by Volynskoi zemli s drievniejshykh vremion do kontsa XIV veka [The fate of Volyn Land from ancient times to the end of the 14th century]. Odessa. [in Russian]

12. Domontovich, M., 1865. Matierialy dlia geografii i statistiki Rossii, sobrannyie ofitserami General'nogo shtaba.Chernigovskaia guberniya [Materials for the geography and statistics of Russia, collected by officers of the General Staff. Chernigov Province]. SPb.: Tip. F. Persona. [in Russian].

13. Yefimenko, A. Ya., 1895. Ocherki istorii pravobierezhnoi Ukrainy [Essays of the history of the Right Bank Ukraine]. Kiev: Tip. G. T. Korchak-Novitskogo. [in Russian].

14. Yefimenko, A. Ya., 1905. Yuzhnaia Rus': ocherki, issliedovaniia, zametki [Southern Russia: essays, research, notes]: v 2 t. Vol. 1. SPb.: Knigopechatnia Shmidta. [in Russian].

15. Tieodorovich, N. I., 1888. Istoriko-statisticheskoie opisaniie tserkviei i prikhodov Volynskoi yeparkhii [Historical and statistical description of churches and parishes of the Volyn diocese]. Vol. 1. Pochaiev. [in Russian].

16. Bagaliei, D., 1882. Istoriia Severskoi ziemli do poloviny XIV st. Istoricheskaia monografiia [History of the Severskaia Land up to half of the XIV c. Historical monograph]. Kiev: $\mathrm{V}$ universitetskoi tipografii (I. I. Zavadskogo). [in Russian].

17. Ocherk istorii goroda Chernigova, 907-1907 [Essay of the history of the city of Chernigov, 9071907]: yubil. izd. Chernigov. Gor. Upravy, 1908. Chernigov: Tip. Gub. Zemstva. [in Russian].

18. Lazarevskii, A. M., 1888. Opisaniie staroi Malorossii. Vol. 1. Polk Starodubskii [Description of old Little Russia. Vol. 1. Starodubsky Regiment]. Kiev. [in Russian].

19. Lazarevskii, A. M., 1893. Opisaniie staroi Malorossii. Vol. 2. Polk Niezhynskii [Description of old Little Russia. Vol. 2. Niezhynsky Regiment]. Kiev. [in Russian].

20. Barvinskii, V., 1908. Do istorii zakriposchennia selian v Livobichnii Ukraini [To the history of fixing peasants in Left-Bank Ukraine]. Zapysky NTSh, 81(1), pp. 154-155. Miscellanea. [in Ukrainian].

21. Barvinskii, V., 1909. Materily do istorii suspil'nogo ta ekonomichnogo pobutu Livoberezhnji Ukrainy v XVIII [Materials to the history of social and economic life of Left-Bank Ukraine in the XVIII c.]. Zapysky NTSh, 90(4), pp. 154-155. [in Ukrainian].

Отримано: 03.12.2020 p. 